\title{
Analisis Hubungan Antara Sanitasi Lingkungan dengan Kejadian Stunting di Kecamatan Cepu, Kabupaten Blora, Jawa Tengah
}

\author{
Maudy Risma Slodia*, Prehatin Trirahayu Ningrum, Sulistiyani \\ Bagian Kesehatan Lingkungan, Fakultas Kesehatan Masyarakat, Universitas Jember, Jawa Timur 68121, Indonesia \\ *Corresponding author: slodia.maudy06@gmail.com
}

Info Artikel:Diterima 8 Mei 2021 ; Direvisi 9 Januari 2022 ; Disetujui 24 Januari 2022

Tersedia online : 8 Februari 2022 ; Diterbitkan secara teratur : Februari 2022

Cara sitasi (Vancouver): Slodia MR, Ningrum PT, Sulistiyani S. Analisis Hubungan Antara Sanitasi Lingkungan dengan Kejadian Stunting di Kecamatan Cepu, Kabupaten Blora, Jawa Tengah. Jurnal Kesehatan Lingkungan Indonesia [Online]. 2022 Feb;21(1):59-64. https://doi.org/10.14710/jkli.21.1.59-64.

\begin{abstract}
ABSTRAK
Latar belakang: Permasalahan gizi, sanitasi, dan lingkungan menjadi pemicu masalah stunting di Indonesia. Kejadian stunting yang terdapat di Indonesia sebesar 30,8\% dan Kabupaten Blora Provinsi Jawa Tengah menjadi yang mempunyai prelevansi stunting yang cukup tinggi. Kecamatan Cepu di Kabupaten Blora mencatat warganya 52,61\% memiliki jamban yang tidak aman dan 24,67\% masih buang air besar sembarangan serta pengelolaan sampah juga masih tidak teratur. Tujuan dari penelitian ini adalah untuk menggambarkan kondisi sanitasi lingkungan dan menganalisis hubungan sanitasi lingkungan dengan terjadinya stunting di wilayah kerja Puskesmas Kapuan, Cepu.

Metode: Jenis penelitian ini adalah penelitian analitik observasional dengan pendekatan kuantitatif dan desain studi case-control. Data yang diperoleh pada penelitian ini adalah data primer berupa kuesioner melalui wawancara dan observasi. Sedangkan data sekunder adalah dokumentasi dan laporan dari dinas terkait. Uji yang digunakan adalah cross tabulation, chi-square, dan regresi logistic.

Hasil: Faktor terkuat penyebab stunting adalah asupan makanan yang diterima balita, yaitu dengan hasil uji nilai $\mathrm{p}$ asupan energi terhadap stunting adalah 0,03 atau $<0,05$. Sedangkan sanitasi lingkungan tidak berhubungan dengan jenis infeksi yang menyebabkan stunting. Mayoritas balita kelompok kasus memiliki riwayat infeksi akan mudah mengalami stunting.

Simpulan: Variabel yang memiliki hubungan dengan stunting adalah asupan gizi dan riwayat infeksi balita. Sedangkan variabel yang tidak berhubungan langsung seperti sanitasi dan karakteristik responden tidak berhubungan dengan stunting.
\end{abstract}

Kata kunci: Stunting; Sanitasi lingkungan; Asupan gizi; Balita

\section{ABSTRACT}

Title: Analysis of Relation Between Environmental Sanitation and Stunting Cases in Cepu, Blora District, Central Java Province.

Background: Nutrition, sanitation, and environmental problems have triggered the emergence of stunting problems in Indonesia. The incidence of stunting in Indonesia is 30.8\%) and Blora Regency, Central Java Province, has a fairly high prevalence of stunting. Cepu Subdistrict in Blora Regency recorded that 52.61\% of residents have unsafe toilets and $24.67 \%$ still defecate in open defecation and irregular waste management. The purpose of this study was to describe environmental sanitation conditions and to analyze the relationship between environmental sanitation and the incidence of stunting in the working area of Puskesmas Kapuan Сери. 
Method: The type of research was an observational analytic study with a quantitative approach and a case control study design. The data obtained in this study were primary data in the form of a questionnaire through interviews and observations. Meanwhile, secondary data was documentation and reports from related agencies. Analysis using cross tabulation, chi square and logistic regression.

Result: Main caused of stunting is food intake received by toddlers with the $p$ value of energy intake is 0.03 or $<0.05$. Meanwhile, environmental sanitation is not related to the type of infection that causes stunting. The majority of toddlers in the case group have a history of infection and will easily experience stunting.

Conclusion: Variables that have a relation with stunting are nutritional intake and infection history of toddlers. Meanwhile, variables that are not directly related, such as sanitation and respondent characteristics, are not related to stunting.

Keywords: Stunting; Environment sanitation; Nutritional intake

\section{PENDAHULUAN}

Permasalahan gizi adalah salah satu masalah yang sering terjadi dalam kesehatan masyarakat. Contoh dari permasalahan gizi adalah malnutrisi, dimana malnutrisi merupakan penyebab 2,6 juta bayi di dunia meninggal tiap tahunnya ${ }^{1}$. Permasalahan gizi ini menyebabkan stunting. Stunting sendiri merupakan kondisi dimana balita memiliki panjang atau tinggi badan yang kurang jika dibandingkan dengan anak lain seusianya. Kondisi ini diukur dengan panjang atau tinggi badan yang lebih dari minus dua standar deviasi median standar pertumbuhan anak dari $\mathrm{WHO}^{2}$. Pemicu terjadinya stunting bisa berasal dari beberapa hal seperti higiene personal, sanitasi dasar, dan konsidi rumah yang tidak sehat. Sanitasi disebut layak jika sarana yang digunakan sudah sesuai dengan persyaratan kesehatan.

Jumlah kejadian stunting yang terdapat di Indonesia sebesar $30,8 \%$. Apabila prevalensi stunting melebihi $20 \%$ maka ditetapkan sebagai masalah kesehatan masyarakat. Menurut WHO prevalensi stunting lebih dari $20 \%$ merupakan masalah gizi masyarakat kronis ${ }^{2}$. Jawa Tengah merupakan salah satu provinsi yang tercatat memiliki prelevansi stunting tertinggi di Indonesia khususnya. Prevalensi stunting di Kabupaten Blora terbilang tinggi yaitu sebesar 55,06\% di tahun 2013, 32\% di tahun 2018 dan $30 \%$ di tahun 2020 serta merupakan salah satu dari 100 kabupaten/kota prioritas penanganan stunting ${ }^{3}$ serta 260 kabupaten/kota prioritas penanganan stunting pada tahun 2020 .

Cepu merupakan sebuah kecamatan di Kabupaten Blora dengan 11 desa dan 6 kelurahan. Tercatat sebanyak $52,61 \%$ di Kecamatan Cepu memiliki jamban tidak aman dan $24,67 \%$ masih melakukan buang air besar sembarangan. Sedangkan pengelolaan sampah hanya sebesar $23 \%$ di wilayah perkotaan ${ }^{4}$. Data studi pendahuluan yang telah dilakukan pada bulan Oktober dan November 2019 menunjukkan pada daerah penelitian terdapat $25,9 \%$ penduduk yang belum memenuhi syarat rumah sehat, sedangkan berdasarkan hasil verifikasi Sanitasi Total Berbasis Masyaratkat (STBM) pada tahun 2019 disimpulkan bahwa belum memenuhi kriteria Desa STBM yang disebabkan salah satunya karena perilaku pengelolaan sampah rumah tangga yang kurang tepat. Atas dasar belum terpenuhinya sarana sanitasi, adanya kejadian infeksi dan asupan makanan balita belum terdata rapi maka perlu diadakannya penelitian di Kecamatan Cepu tentang sanitasi lingkungan dengan kejadian stunting.

\section{MATERI DAN METODE}

Penelitian ini merupakan jenis penelitian analitik observasional dan desain studi case kontrol yang menggunakan pendekatan kuantitatif. Daerah penelitian, lokus stunting Kecamatan Cepu yaitu wilayah kerja Puskesmas Kapuan yang memiliki populasi ibu dari balita berusia $24-59$ bulan sebanyak 276 orang. Teknik pengambilan sampel kasus menggunakan total random sampling dengan menghitung sampel minimal dengan antisipasi dropout. Sedangkan teknik pengambilan sampel control menggunakan perbandingan 1:1 dengan sampel kasus yang telah didapatkan berdasarkan perhitungan, serta ditentukan secara random denan matching. Kemudian didapatkan kesimpulan pada penelitian ini sampel kasus yaitu 26 orang dan sampel kontrol, yaitu 26 orang. Data penelitian terbagi menjadi dua yakni primer yang berasal dari kuesioner melalui wawancara dan observasi dan sekunder yang didapat dari dokumentasi serta laporan yang terdahulu. Data penelitian dianalisis menggunakan analisis univariat (cross tabulation), bivarat (chisquare), dan multivarat (regresi logistik).

\section{HASIL DAN PEMBAHASAN}

Responden dalam penelitian ini adalah ibu dari balita yang berusia $24-59$ bulan dan dibagi menjadi dua kelompok. Kelompok kasus yang terdiri dari ibu dengan balita stunting dan kelompok kontrol adalah ibu dari balita tidak stunting. Hasil dari analisis univariat menggunakan cross tabulatio menunjukkan bahwa sebanyak 13 orang ibu yang berada pada kelompok kasus dan $13(50 \%)$ orang ibu yang memiliki balita tidak stunting dengan rentang usia sama yakni 26 tahun hingga 35 tahun. Kemampuan ibu dalam berfikir dan memutuskan sebuah pilihan adalah berbanding lurus dengan pendidikan terakhir yang ditempuh. Hasil analisis cross tabulation menunjukkan bahwa kategori pendidikan diploma, 
sarjana dan seterusnya hanya terdapat $1(3,9 \%)$ yang masuk kelompok kasus dan $2(7,7 \%)$ masuk kelompok kontrol. Kelompok kasus sebanyak 20 $(26,9 \%)$ ibu tidak bekerja dan responden dari kelompok kontrol adalah $19 \quad(73,1 \%)$ ibu tidak bekerja. Keluarga yang memiliki pendapatan cukup akan mempunyasi sistem pertahanan yang bagus juga namun mayoritas dari kelompok kasus dan kelompok kontrol masih berpenghasilan di bawah UMK atau di bawah Rp. 1.834.000,-. Pada kelompok kasus dan kelompok responden mayoritas memiliki anggota keluarga lebih dari 4 orang.

Asupan makanan pada anak sangat dibutuhkan karena berpengaruh pada tumbuh kembang seperti berat badan, usia, dan tinggi badan. Oleh sebab itu asupan gizi penting untuk diteliti pada masalah stunting. Pada penelitian ini pemenuhan asupan makanan pada balita dibagi menjadi 5 kategori, yaitu defisit berat apabila nilai hitung energi total $<70 \%$ anjuran, defisit sedang 70\%-79\% dari anjuran, dan defisit ringan apabila terhitung 80\%-89\% dari anjuran, dikatakan normal apabila berkisar 90\%-120\% anjuran dan lebih apabila nilai hitung energi totalnya $>120 \%$.

Tabel. 1 Asupan Makanan Balita Responden

\begin{tabular}{lcccc}
\hline \multirow{2}{*}{$\begin{array}{c}\text { Asupan Makanan } \\
\text { Balita }\end{array}$} & \multicolumn{2}{c}{ Kasus } & \multicolumn{2}{c}{ Kontrol } \\
\cline { 2 - 5 } & $\mathbf{n}$ & $\mathbf{\%}$ & $\mathbf{n}$ & $\mathbf{\%}$ \\
\hline Defisit Berat & 10 & 38,5 & 0 & 0 \\
Defisit Sedang & 6 & 23,1 & 0 & 0 \\
Defisit Ringan & 7 & 26,9 & 7 & 26,9 \\
Normal & 2 & 7,7 & 14 & 53,8 \\
Lebih & 1 & 3,8 & 5 & 19,2 \\
\hline Total & $\mathbf{2 6}$ & $\mathbf{1 0 0}$ & $\mathbf{2 6}$ & $\mathbf{1 0 0}$ \\
\hline
\end{tabular}

Pada tabel 1 dapat dinyatakan bahwa mayoritas balita responden kelompok kasus tidak mendapatkan asupan makanan yang cukup karena 88,5\% di antaranya mengalami defisit ringan hingga berat. Sedangkan balita pada responden kelompok kontrol mendapatkan asupan makanan yang cukup karena $57,7 \%$ di antaranya dikategorikan dalam asupan makanan normal.

Hasil penelitian dari riwayat infeksi yang dialami oleh balita dapat memberatkan kinerja tubuh dalam proses penyerapan gizi makanan. Apablia infeksi terjadi berulang maka berdampak pada keterlambatan tumbuh kembangnya.

Tabel 2. Riwayat Infeksi Pada Balita

\begin{tabular}{lcccc}
\hline \multirow{2}{*}{ Riwayat Infeksi } & \multicolumn{2}{c}{ Kasus } & \multicolumn{2}{c}{ Kontrol } \\
\cline { 2 - 5 } & $\mathbf{n}$ & $\mathbf{\%}$ & $\mathbf{n}$ & $\mathbf{\%}$ \\
\hline Jenis Infeksi & & & & \\
Tidak pernah & 9 & 34,6 & 16 & 61,5 \\
Diare & 3 & 11,6 & 0 & 0 \\
Lainnya & 14 & 53,8 & 10 & 38,5 \\
\hline Total & $\mathbf{2 6}$ & $\mathbf{1 0 0}$ & $\mathbf{2 6}$ & $\mathbf{1 0 0}$ \\
\hline Frekuensi & & & & \\
Tidak pernah & 9 & 34,6 & 16 & 61,5 \\
$\leq 6$ kali & 16 & 61,5 & 10 & 38,5 \\
$>$ 6 kali & 1 & 3,9 & 0 & 0 \\
\hline Total & $\mathbf{2 6}$ & $\mathbf{1 0 0}$ & $\mathbf{2 6}$ & $\mathbf{1 0 0}$ \\
\hline
\end{tabular}

Dari data tabel 2 menunjukkan bahwa responden dari kelompok kasus memiliki mayoritas balita mengalami riwayat infeksi dengan kategori lainnya, dimana infeksi ini adalah demam yang sering terjadi saat pergantian musim atau cuaca ekstrim di Cepu. Sedangkan pada kelompok kontrol mayoritas balita tidak pernah mengalami riwayat infeksi. Infeksi campak dan batuk rejan baik dari kelompok kasus dan kelompok control responden tidak mengalami gejala.

Lingkungan yang baik dapat meningkatkan kualitas kesehatan sebuah keluarga. Jika kualitas kesehatan meningkat maka tidak mudah untuk terpapar agen penyakit. Persyaratan pertama adalah komponen rumah yang meliputi kondisi fisik serta bahan bangunan rumah. Rumah dapat dikatakan apabila memiliki komponen rumah lengkap dengan skor hasil observasi 310-465, sedangkan apabila skor hasil observasi $<310$ maka dikatakan rumah tersebut memiliki komponen yang tidak lengkap. Pada tabel 2 diketahui bahwa responden kelompok kasus mayoritas kondisi rumahnya tidak memiliki langit-langit, tidak berdinding permanen, berlntaikan tanah, kamar tidak berjendela, memiliki ruang keluarga berjendela, lubang asap dapur kurang dari 10\%, luas lantai dan pencahayaan kurang terang. Sedangkan responden kelompok kontrol mayoritas memiliki langit-langit, berdinding semi permanen, berlantai tanah, memiliki jendela di kamar tidur, memiliki jendela di ruang keluarga, luas ventilasi lebih dari 10\% luas lantai, lubang asap dapur kurang ari 10\% luas lantai dan pencahayaan yang terang. Dapat dikatakan bahwa mayoritas responden memiliki total skor dengan kategori tidak lengkap dalam kriteria ini, yaitu sebanyak $18(69,2 \%)$ rumah responden tidak lengkap dari kelompok kasus dan $14 \quad(53,8 \%)$ rumah responden tidak lengkap dari kelompok kontrol.

Persyaratan selanjutnya adalah sarana sanitasi dasar yang seharusnya dimiliki setiap rumah. Karena sanitasi ini berhubungan dengan akses air bersih, keberadaan jamban, saluran pembuangan air limbah dan pengelolaan sampah.

\section{Tabel 3. Sarana Sanitasi (Air Bersih)}

\begin{tabular}{lcccc}
\multicolumn{1}{c}{ Kriteria } & \multicolumn{2}{c}{ Kasus } & \multicolumn{2}{c}{ Kontrol } \\
\cline { 2 - 5 } & $\mathbf{n}$ & $\mathbf{\%}$ & $\mathbf{n}$ & $\%$ \\
\hline $\begin{array}{l}\text { Sarana Air Bersih } \\
\text { Ada, bukan milik }\end{array}$ & 0 & 0 & 2 & 7,7 \\
$\begin{array}{l}\text { sendiri, memenuhi } \\
\text { syarat kesehatan, }\end{array}$ & & & & \\
tidak mencukupi & & & & \\
kebutuhan & & & & \\
$\begin{array}{l}\text { Ada, milik sendiri, } \\
\text { memenuhi syarat }\end{array}$ & 26 & 100 & 24 & 92,3 \\
kesehatan, & & & & \\
mencukupi & & & & \\
kebutuhan & & & & \\
\hline Total & & & & \\
\hline $\begin{array}{l}\text { Sumber Air Bersih } \\
\text { Sumur bor }\end{array}$ & $\mathbf{2 6}$ & $\mathbf{1 0 0}$ & $\mathbf{2 6}$ & $\mathbf{1 0 0}$ \\
$\begin{array}{l}\text { PAM } \\
\text { Total }\end{array}$ & 19 & 73,1 & 15 & 57,7 \\
\hline
\end{tabular}


Pada tabel 3 ini informasi yang bisa didapat adalah bahwa semua mempunyai sarana air bersih . kelompok kasus, seluruh responden memiliki sumber air bersih yang bersifat pribadi dimana $19(73,1 \%)$ responden diantaranya menggunakan jenis sumber air bersih berupa PAM. Sedangkan pada kelompok kontrol sebanyak 24 (92,3\%) responden menggunakan sumber air bersih yang bersifat pribadi dengan 15 $(57,7 \%)$ diantaranya menggunakan jenis air bersih berupa PAM.

Tabel 4. Sarana Sanitas (Jamban)

\begin{tabular}{|c|c|c|c|c|}
\hline \multirow{2}{*}{ Kriteria } & \multicolumn{2}{|c|}{ Kasus } & \multicolumn{2}{|c|}{ Kontrol } \\
\hline & $\mathbf{N}$ & $\%$ & $\mathbf{N}$ & $\%$ \\
\hline $\begin{array}{l}\text { Keberadaan jamban } \\
\text { Ada, leher angsa, } \\
\text { menggunakan septic tank, } \\
\text { memenuhi syarat } \\
\text { kesehatan }\end{array}$ & 26 & 100 & 26 & 100 \\
\hline Total & 26 & 100 & 26 & 100 \\
\hline $\begin{array}{l}\text { Jenis jamban } \\
\text { Leher angsa }\end{array}$ & 26 & 100 & 26 & 100 \\
\hline Total & 26 & 100 & 26 & 100 \\
\hline
\end{tabular}

Dapat diketahui bahwa kelompok kasus dan kelompok kontrol sama-sama memiliki jamban berjenis leher angsa dengan tutup, jauh dari sumber air minum, memiliki sabun di dalamnya, dan saluran akhir septic tank. Keseluruhan jamban sudah memenuhi prersyaratan kesehatan.

Pada sarana sanitasi pembuangan limbah rumah tangga sebanyak $26(100 \%)$ responden kelompok kasus dan $15(57,7 \%)$ responden kelompok kontrol memiliki saluran pembuangan air limbah yang dialirkan pada selokan terbuka yang dapat menjadi tempat perkembang biakan vektor. Sedangkan limbah padat rumah tangga responden kelompok kasus dan kontrol tidak diolah dengan baik. Hal ini disebabkan $19(73,1 \%)$ responden kelompok kasus tidak memiliki tempat pembuangan sampah sementara, sehingga dibuang di pekarangan rumah dan seluruhnya 26 $(100 \%)$ responden melakukan pengolahan terakhir dengan dibakar, sedangkan pada kelompok kontrol sebanyak $23(88,5 \%)$ responden tidak memiliki tempat pembuangan sampah sementara, dibuang di pekarangan rumah dan seluruhnya $26 \quad(100 \%)$ melakukan pengolahan terakhir dengan dibakar. Berdasarkan penilaian, rumah dapat dikatakan memiliki sarana sanitasi dasar yang layak apabila skor hasil observasi 450-600.

Pada persyaratan perilaku penghuni rumah mengenai indikator menjaga kebersihan rumah pada kelompok kasus sebagian besar $17 \quad(65,4 \%)$ berperilaku bersih dan kelompok kontrol juga mayoritas berperilaku bersih dengan jumlah 21 $(80,8 \%)$.
Tabel 5. Sanitasi Lingkungan

\begin{tabular}{lcccc}
\hline \multirow{2}{*}{ Kriteria } & \multicolumn{2}{c}{ Kasus } & \multicolumn{2}{c}{ Kontrol } \\
\cline { 2 - 5 } & $\mathbf{n}$ & $\mathbf{\%}$ & $\mathbf{n}$ & $\mathbf{\%}$ \\
\hline Memenuhi syarat & 6 & 23,1 & 10 & 38,5 \\
Tidak memenuhi & 20 & 76,9 & 16 & 61,5 \\
syarat & & & & \\
\hline Total & $\mathbf{2 6}$ & $\mathbf{1 0 0}$ & $\mathbf{2 6}$ & $\mathbf{1 0 0}$ \\
\hline
\end{tabular}

Ketiga persyaratan tersebut dijumlah dan dihitung secara keseluruhan lalu mendapatkan hasil berupa rumah yang memenuhi syarat kesehatan. Rumah dikatakan bersanitasi lingkungan baik dan memenuhi syarat kesehatan apabila skor total 106810505, dan dikatakan buruk atau tidak memenuhi syarat kesehatan jika skor total $<1068$. Dapat diketahui bahwa 20 (76,9\%) dari responden kelompok kasus total skornya tidak memenuhi kriteria kesehatan sedangkan tak jauh berbeda kelompok kontrol juga memiliki $16(61,5 \%)$ responden yang dikategorikan tidak memenuhi syarat kesehatan.

Semua variabel yang diteliti dalam penelitian ini selanjutnya dianalisis dengan menggunakan analisis multivariate untuk mengetahui variabel yang memiliki hubungan paling besardengan kejadian stunting. Uji yang digunakan adalah regresi logistik karena skala data dalam penelitian ini berupa kategorikal. Untuk melakukan uji ini, maka sebelunya melihat hasil chisquare dari variabel terkait dengan variabel terikat, apabila memiliki hasil berhubungan maka dapat dilakukan uji regresi ini. Hasil dari analisis multivariat menggunakan uji regresi logistic.

Tabel 6. Hubungan Karakteristik Responden, Sanitasi Lingkungan, Asupan Makanan Balita, Riwayat Infeksi Dengan Kejadian Stunting

\begin{tabular}{lccc}
\hline Variabel & Koefisien & p-value & OR \\
\hline Karakteristik Responden & & & \\
Usia & 0,26 & 0,80 & 1,30 \\
Pendidikan terakhir & $-1,46$ & 0,96 & 0,86 \\
Jenis pekerjaan & 1,04 & 0,43 & 2,83 \\
Pendapatan tiap bulan & 0,94 & 0,52 & 2,54 \\
Jumlah anggota keluarga & $-0,83$ & 0,54 & 0,43 \\
\hline Asupan Makanan Balita & $-4,72$ & $<0,001$ & 0,31 \\
\hline Riwayat Infeksi & & & \\
Infeksi & 21,86 & 0,99 & 3,12 \\
Frekuensi Infeksi & $-21,65$ & 1,00 & 0,00 \\
\hline Sanitasi Lingkungan & & & \\
Komponen rumah & -0.19 & 0,89 & 0,83 \\
Sarana sanitasi & $-19,52$ & 0,99 & 0,00 \\
Perilaku penghuni & $-1,64$ & 1,13 & 0,19 \\
Sanitasi Lingkungan RT & 2,19 & 1,17 & 8,95 \\
\hline Konstanta & 21,19 & 1,00 & 1,59 \\
\hline
\end{tabular}

Pada data menunjukkan bahwa nilai $p$ dari seluruh variable, yang memiliki nilai signifikan dengan status stunting pada balita adalah variabel asupan makanan balita $(\mathrm{OR}=0,31)$ dengan nilai $p$ sebesar $<0,001$ yang memiliki arti $<0,05$ sehingga dapat ditarik kesimpulan bahwa balita yang mengalami defisit pada asupan makanannya berisik 0,31 kali mengalami stunting. 
Melalui recall 2x24 jam pada balita respoden, peneliti dapat mengetahui jumlah asupan energy yang didapat dalam makanan sehari-hari. Balita yang terpenuhi kebutuhan energi totalnya cenderung lebih sehat dan bertumbuh secara normal atau tidak mengalami keterlambatan dibandingkan dengan balita yang kurang terpenuhi kebutuhan energi totalnya. Variabel karakteristik responden yang meliputi usia ibu, pendidikan terakhir ibu, jenis pekerjaan ibu, pendapatan keluarga, jumlah anggota keluarga tidak memiliki hubungan yang signifikan dengan kejadian stunting. Hal ini dibuktikan dengan nilai $p$ lebih besar dari 0,05 yang berarti variabel tersebut tidak memiliki hubungan berdasarkan uji regresi logistic. Usia ibu yang tergolong muda $(<35$ tahun $)$ memiliki pengetahuan yang terbatas terkait dengan gizi baik pada saat mengandung hingga pasca melahirkan. Selain itu pendidikan ibu yang rendah menyebabkan ibu kurang tanggap dalam mengambil keputusan. Pendapat yang berbeda dikemukakan oleh Labada et al., 5 pada penelitiannya, bahwa jumlah anggota keluarga memiliki hubungan dengan kejadian stunting. Hal ini disebabkan keluarga yang memiliki anggota banyak cenderung memiliki kebutuhan yang banyak untuk dipenuhi sehingga alokasi pengeluaran tidak seimbang dengan pendapatan yang rendah. Perbedaan teori dengan hasil penelitian disebabkan oleh jenis uji yang dilakukan oleh peneliti. Peneliti terdahulu melakukan uji secara langsung, sedangkan pada penelitian kali ini menggunakan variabel antara yang merupakan faktor langsung, maka uji yang dilakukan mengikuti kaidah penelitian dan kerangka konsep peneliti. Selain itu, hal mendasar yang menyebabkan karakteristik responden tidak berhubungan dengan kejadian stunting adalah karena tidak adanya perbedaan mencolok dalam variabel karakteristik responden, baik dari kelompok kasus maupun kelompok kontrol. Sedangkan variabel sanitasi lingkungan, memiliki hasil uji tidak memiliki hubungan. Berdasarkan observasi yang telah dilakukan memberikan informasi bahwa mayoritas responden memiliki rumah semi permanen, berlantaikan tanah, dan tidak memiliki langit-langit serta jendela atau sarana ventilasi kurang mencukupi. Selain itu, pemanfaatan sarana sanitasi dapat dikatakan kurang, khususnya dalam pengolahan sampah yang mayoritas masih dibakar. Pembakaran sampah dilakukan karena menurut responen hal tersebut lebih cepat dan ringkas daripada harus memilah dan melakukan pengolahan yang lebih baik. Pendapat Laili ${ }^{6}$ dalam penelitian di Sumberjambe, Kabupaten Jember, memiliki hasil uji yang sama yaitu bahwa sanitasi lingkungan tidak berhubungan dengan stunting. Lain halnya dengan penelitian yang dilakukan oleh Soerachmad et al. di Sulawesi selatan yang menunjukkan hasil uji bahwa adanya hubungan antara akses air bersih, pengamanan sampah rumah tangga dan pengelolaan air minum ${ }^{7}$. Selain itu, menurut Humphrey ScD et al., juga mengatakan berdasarkan hasil penelitiannya bahwa tidak terapat hubungan antara sanitasi dan hygiene dengan kejadian stunting ${ }^{8}$.

Perbedaan antara teori pada kerangka penelitian dan hasil uji dapat dikarenakan perbedaan sosiodemografi pada masing-masing tempat penelitian. Daerah penelitian wilayah kerja Puskesmas Kapuan yang termasuk sebagai wilayah pedesaan diketahui bahwa mayoritas masyarakat memiliki model rumah dan budaya yang sama, yaitu rumah tradisional dan budaya skeptis mengenai pendidikan wanita. Selain itu, mayoritas penelitian menggunakan desain studi cross-sectionalyang dapat menjadi penyebab adanya perbedaan hasil yang signifikan'. Kemungkinan lain adalah adanya faktor yang lebih berperan dalam kejadian stunting seperti pemberian asupan makanan balita pada balita tergolong mencukupi kebutuhan walaupun sanitasi lingkungan tidak memenuhi persyaratan atau dikatakan tidak layak ${ }^{10}$.

\section{SIMPULAN}

Penelitian ini menyimpulkan beberapa hal yakni, 1) Responden penelitian mayoritas berada pada rentang usia 26-35 tahun, dengan pendidikan terakhir lulusan SD-SMP, tidak bekerja, mempunyai tingkat pendapatan keluarga kurang dari UMK dan memiliki anggota keluarga lebih dari 4 orang. Asupan gizi pada responden kelompok kasus dikategorikan kurang, sedangkan pada kelompok kontrol termasuk cukup. Mayoritas kelompok kasus mengalami demam dan flu dengan frekuensi $\leq 6 \mathrm{kali}$, sedangkan balita pada kelompok kontrol tidak mengalaminya pada setahun terakhir. Sanitasi lingkungan rumah pada mayoritas responden baik kelompok kasus maupun kontrol tidak memenuhi syarat kesehatan 2) Tidak terdapat hubungan antara karakteristik responden dengan asupan gizi balita. 3) Terdapat hubungan anatara asupan makanan balita dengan kejadian stunting. 4) Tidak terdapat hubungan antara sanitasi lingkungan dengan riwayat infeksi. 5) Tidak terdapat hubungan antara riwayat infeksi dengan kejadian stunting. 6) Hasil regresi logistik menunjukkan bahwa faktor tidak langsung dari kejadian stunting yakni karakteristik responden dan sanitasi lingkungan tidak berhubungan dengan kasus stunting.

\section{DAFTAR PUSTAKA}

1 Ramayulis, R., Kresnawan, T., \& Iwaningsih, S. 2018. Stop stunting dengan konseling gizi. Jakarta: Penebar Plus.

2 Kemenkes RI. 2018. Buletin Stunting: Situasi Balita Pendek (Stunting) Di Indonesia. Kementerian Kesehatan RI, 301(5), 1163-1178. https://pusdatin.kemkes.go.id

3 TNP2K. 2017. 100 Kabupaten/Kota Prioritas untuk Intervensi Anak Kerdil (Stunting) VOLUME 1. Jakarta: Sekertariat Wakil Presiden Republik Indonesia.

4 Bappeda Blora. 2018. Review Pemutakhiran Strategi Sanitasi Kabupaten (SSK ) Kabupaten Blora Tahun 2018-2022. In Review 
Pemutakhiran Strategi Sanitasi Kabupaten Blora. https://sippa.ciptakarya.pu.go.id/

5 Labada, A., Ismanto, A., Kundre, R., Studi, P., Keperawatan, I., Kedokteran, F., Sam, U., \& Manado, R. 2016. Hubungan Karakteristik Ibu Dengan Status Gizi Balita Yang Berkunjung Di Puskesmas Bahu Manado. Jurnal Keperawatan, 4(1). https://ejournal.unsrat.ac.id/

6 Laili, A. N. 2018. Analisis Determinan Kejadian Stunting Pada Balita. Skripsi. Jember: Program Studi Ilmu Kesehatan Masyarakat Pascasarjana FKM Universitas Jember.

7 Soerachmad, Y., Ikhtiar, M., Bintara, A. S., Pasca Sarjana, P., \& Kesehatan Lingkungan, prodi. 2019. Hubungan Sanitasi Lingkungan Rumah Tangga Dengan Kejadian Stunting Pada Anak Balita Di Puskesmas Wonomulyo Kabupaten polewali Mandar Tahun 2019. Jurnal Kesehatan Masyarakat, 5(2), 138-150. https://doi.org/10.35329/jkesmas.v5i2.519

8 Humphrey ScD, J. H., N Mbuya, M. N., Moulton, L. H., Prendergast, A. J., Humphrey, J. H., Ntozini, R., Tavengwa MSW, N. V, Mutasa MPH, K., Majo RGN, F., Mutasa MBA, B., Chasekwa, B., Smith, L. E., Humphrey, J. H., N Mbuya, M. N., Ntozini, R., Moulton, L. H., Stoltzfus, R. J., Tavengwa, N. V, Mutasa, K., ... Prendergast, A. J. 2019. Independent and combined effects of improved water, sanitation, and hygiene, and improved complementary feeding, on child stunting and anaemia in rural Zimbabwe: a cluster-randomised trial. Articles Lancet Glob Health, 7, 132-179. https://doi.org/10.1093/cid/civ844

9 Ismawati, R., Soeyonoa, R. D., Romadhoni, I. F., \& Dwijayanti, I. 2020. Nutrition intake and causative factor of stunting among children aged under-5 years in Lamongan city. Enfermeria Clinica, 30, 71-74. https://doi.org/10.1016/j.enfcli.2019.10.043

10 Badriyah, ul, \& Syafiq, A. 2017. The Association Between Sanitation, Hygiene, and Stunting in Children Under Two-Years (An Analysis of Indonesia's Basic Health Research, 2013). Makara J. Health Res, 21(2), 35. https://doi.org/10.7454/msk.v21i2.6002

11 Keputusan Menteri Kesehatan Nomor 829/Menkes/SK/VII/1999. Persyaratan Kesehatan Perumahan. Kementerian Kesehatan Republik Indonesia.

12 Kusumawati, E., Rahardjo, S., \& Sari, H. P. 2015. Model Pengendalian Faktor Risiko Stunting pada Anak Bawah Tiga Tahun. Kesmas: National Public Health Journal, 9(3), 249. https://doi.org/10.21109/kesmas.v9i3.572
13 Fikawati, S., Syafiq, A., \& Karima, K. 2015. Gizi Ibu dan Bayi. Jakarta: PT Rajagrafindo Persada.

14 Apriluana, G., \& Fikawati, S. 2018. Analisis Faktor-Faktor Risiko terhadap Kejadian Stunting pada Balita (0-59 Bulan) di Negara Berkembang dan Asia Tenggara. Media Penelitian Dan Pengembangan Kesehatan, 28(4), 247-256. https://doi.org/10.22435/mpk.v28i4.472

15 Modern, G., Sauli, E., \& Mpolya, E. 2020. Correlates of diarrhea and stunting among underfive children in Ruvuma, Tanzania; a hospitalbased cross-sectional study. Scientific African, 8, 430. https://doi.org/10.1016/j.sciaf.2020.e00430

16 Novianti, S., \& Padmawati, R. S. 2020. Hubungan Faktor Lingkungan Dan Perilaku Dengan Kejadian Stunting Pada Balita : Scoping Review. Jurnal Kesehatan komunitas Indonesia 16(1). http://jurnal.unsil.ac.id/

17 Rokhmah, D., Moelyaningrum, A. D., Ningtyias, F. W., \& Rohmawati, N. 2021. Stunting: Pencegahan dan Penanganan di Bidang Kesehatan Masyarakat. Malang: Inteligensia Media.

18 Hasan, A., Kadarusman, H., Kesehatan Lingkungan, J., \& Kesehatan Tanjung Karang, P. 2019. Akses ke Sarana Sanitasi Dasar sebagai Faktor Risiko Kejadian Stunting pada Balita Usia 6-59 Bulan. Jurnal Kesehatan, 10(3). https://doi.org/10.26630/jk.v10i3.1451

19 Slamet. 2011. Kesehatan Lingkungan. Yogyakarta: Gadjah Mada University Press.

20 Herawati, H., Anwar, A., \& Setyowati, D. L. 2020. Hubungan Sarana Sanitasi, Perilaku Penghuni, dan Kebiasaan Cuci Tangan Pakai Sabun (CTPS) oleh Ibu dengan Kejadian Pendek (Stunting) pada Batita Usia 6-24 Bulan di Wilayah Kerja Puskesmas Harapan Baru, Samarinda. Jurnal Kesehatan Lingkungan Indonesia, 19(1), 7. https://doi.org/10.14710/jkli.19.1.7-15

21 Sunyono, \& Budiman. 2010. Imu Kesehatan Masyarakat Dalam Konteks Kesehatan Lingkungan. Jakarta: EGC.

22 Supariasa. 2016. Penilaian Status Gizi. Jakarta: EGC.

23 Chandra, B. 2006. Pengantar Kesehatan Lingkungan. Jakarta: EGC.

24 Uliyanti, Tamtomo, D. ., \& Anantanyu, S. 2017. Faktor Yang Berhubungan Dengan Kejadian Stunting Pada Balita Usia 24-59 Bulan Uliyanti1. Jurnal Vokasi Kesehatan, 3(2), 1-11. https://doi.org/10.14710/jkli.19.1.7-15

25 Yuliana, H. 2019. Darurat Stunting dengan Melibatkan Keluarga. Sulawesi Selatan: Yayasan Ahmar Cendrka Indonesia. 